\title{
Detection of Leishmania infantum in the smegma of infected dogs
}

\author{
[Detecção de Leishmania infantum no esmegma de cães infectados] \\ L.C. Silva ${ }^{1}$, V.P. Assis ${ }^{1}$, V.M. Ribeiro ${ }^{1}$, W.L. Tafuri ${ }^{2}$, J.C. Toledo Júnior ${ }^{1}$, \\ S.O. Silva ${ }^{2}$, M.N. Melo ${ }^{2}$, M.A. Rachid ${ }^{2}$, G.R. Valle ${ }^{1 *}$ \\ ${ }^{1}$ Pontifícia Universidade Católica de Minas Gerais - Betim, MG \\ ${ }^{2}$ Instituto de Ciências Biológicas - Universidade Federal de Minas Gerais - Belo Horizonte, MG
}

\begin{abstract}
Considering the venereal transmission of visceral leishmaniasis from dogs to bitches, the aim of this study was to verify if the penile surface and smegma from infected dogs can be the source of parasites in bitches. Twelve Leishmania infantum infected dogs had semen and smegma samples collected for submission to PCR identification of the DNA of the parasite. Semen (41.7\%) and smegma (50.0\%) have similar positive incidence ( $\mathrm{P}>0.05$; Fisher's exact test), with $58.3 \%$ of the dogs positive for semen and/or smegma samples. The proportion of positivity for both semen and smegma was $33.3 \%$, but $8.3 \%$ was positive only for semen, and $16.7 \%$ only for smegma, revealing a moderate agreement between tests ( $\mathrm{K}=0.5$; Kappa index). It was concluded that Leishmania infantum is present in the smegma of contaminated dogs and it can be a source of parasites for the semen and the bitch.
\end{abstract}

Keywords: Leishmania infantum; dog; prepuce, smegma; semen

\section{RESUMO}

Tendo em vista a transmissão venérea da leishmaniose visceral do cão para a cadela, o objetivo deste estudo foi verificar se a superfície peniana e o esmegma de cães infectados poderiam ser a fonte de parasitas para a fêmea. Amostras de sêmen e esmegma de 12 cães infectados com Leishmania infantum foram submetidas à identificação do DNA do parasita por PCR. As incidências de positividade no sêmen $(41,7 \%)$ e no esmegma $(50,0 \%)$ foram semelhantes ( $P>0,05$; teste exato de Fisher), sendo 58,3\% dos cães positivos para sêmen elou esmegma. A positividade para sêmen e esmegma juntos ocorreu em 33,3\%, mas em 8,3\% dos casos apenas no sêmen, e em 16,7\% apenas no esmegma, o que revela uma concordância moderada entre os testes $(K=0,5$; indice Kappa). Conclui-se que a Leishmania infantum está presente no esmegma de cães contaminados, podendo ser a fonte de parasitas para o sêmen e a cadela.

Palavras-chave: Leishmania infantum, cão, prepúcio, esmegma, sêmen

\section{INTRODUCTION}

Visceral Leishmaniasis (VL) is an important zoonotic and systemic parasitic disease widely distributed in the world (Alvar et al., 2012). In dogs, VL is associated with variable clinical manifestations characterized by splenomegaly, limphadenopathy, anemia, pancytopenia, weight loss and weakness (Ciaramella et al., 1997). The disease may also cause male (Diniz et al., 2005) and female genital lesions (Silva et al., 2008).
The transmission of Leishmania (Leishmania) infantum (syn. Leishmania (Leishmania) chagasi) (Mauricio et al., 1999) from dog to dog and from dog to man occurs, in the New World, through bites of infected Lutzomyia longipalpis (Kamhawi, 2006). However, there are descriptions of other forms of transmission in dogs, such as blood transfusions (Owens et al., 2001; Freitas et al., 2006), venereal transmission from dog to bitch (Silva et al., 2009a), and transplacentary vertical transmission (Silva et al., 2009b).

Recebido em 7 de março de 2013

Aceito em 12 de dezembro de 2013

*Autor para correspondência (corresponding author)

E-mail: guilhermerv@pucminas.br 
It is believed that the venereal transmission from dog to bitch occurs due to deposition of the infected semen in the genital tract of the female (Diniz et al., 2005; Silva et al., 2009a). However, it is a plausible hypothesis that the origin of the parasite is the external genitalia of dogs, transferred to the bitch at the moment of the copula (Silva et al., 2009a). Diniz et al. (2005) identified amastigote forms of $L$. infantum by immunohistochemistry in explants from prepuce and penis of infected dogs, but the preputial sheath surface was not investigated.

Canine copulas are preceded by the court phase, when the dog and the bitch lick and sniff each other in the genital area, preceding to the proper copula. Afterwards, the dog mounts the bitch and puts the erectile penis trough the vulva into the vagina, keeping it coupled inside the vagina during the ejaculation period. The ejaculation consists of the emission of three semen fractions: the first and third from the prostate gland, and the second, the sperm rich fraction, from the epididymis. The process takes about 10 minutes, and after that, the erection and copula ends (Johnston et al., 2001).

The aim of the present study was to evaluate the presence of $L$. infantum by PCR in the smegma of naturally infected dogs, as a potential source of the parasite in the semen and the bitch.

\section{MATERIAL E METHODS}

Twelve adult male dogs naturally infected with L. infantum were used, and seven of those were patients of a veterinary clinic in Belo Horizonte, Minas Gerais, Brazil (1 English Bulldog, 1 Border Collie, 1 German Shepherd, 1 Italian Greyhound, 1 Poodle, 1 Weimaraner, and 1 Scottish Terrier) and the other five were mongrel dogs from the Municipal Zoonotic Disease Control Department of Betim, Minas Gerais, Brazil. They were all symptomatic dogs with a variety of clinical signs. The diagnosis of Canine Visceral Leishmaniasis (CVL) was confirmed through microscopic identification of the amastigote forms of $L$. infantum inside macrophages from bone marrow or lymph node aspirative smears stained with Giemsa (Moreira et al., 2007).

Samples from one adult Poodle dog were used as negative control. The dog was characterized as negative for $L$. infantum infection from parasitologic negative Giemsa stained smear of bone marrow; negative PCR of bone marrow; and negative title on immunofluorescence antibody test (IFAT).

Samples from one adult infected mongrel dog were used as positive control. The dog was characterized as positive for $L$. infantum infection from parasitologic positive Giemsa stained smear of bone marrow; positive PCR of bone marrow; and positive title (1:640) on IFAT.

After the external hygiene of the prepuce with a dry paper towel, one sterile cotton swab, moistened with sterile $0.9 \%$ sodium chloride solution, was introduced through preputial ostium to collect the smegma on the internal surface of the preputial sheath and glans penis. The swab was broken and the cotton tip was transferred to sterile tubes and stored at $-20^{\circ} \mathrm{C}$ until analysis.

Following the smegma sample collection, each dog was submitted to semen collection by penile manipulation, collecting the ejaculate in a sterile glass tube coupled with a plastic funnel (Johnston et al., 2001). Only ejaculates containing epididymal sperm rich fraction were used, characterized by live motile spermatozoa present in a drop microscopically analyzed between a slide and a coverslip (Assis et al., 2010). Samples of $0.5 \mathrm{~mL}$ from these ejaculates were also transferred to sterile tubes and stored at $-20^{\circ} \mathrm{C}$ until analysis.

The DNA purification from smegma and semen was carried out as described by Strauss-Yali et al. (2004), with modifications. Each sample received $300 \mu \mathrm{L}$ of lysis buffer $(50 \mathrm{mMol} / \mathrm{L}$ Tris, $50 \mathrm{mM} / \mathrm{L} \mathrm{NaCl}$ and $10 \mathrm{mM} /$ EDTA, pH 8.0 ) containing proteinase $\mathrm{K}(250 \mathrm{~g} / \mathrm{mL})$ and Triton $\mathrm{X}-100(1 \%)$. After incubation $\left(2 \mathrm{~h}\right.$ at $\left.56^{\circ} \mathrm{C}\right)$, the solution was eluted from the samples, transferred into phase-lock gel tube PLG-H (Eppendorf) and mixed with $500 \mu \mathrm{L}$ of $75 \%$ Tris saturated phenol and $25 \%$ chloroform-isoamyl alcohol. The organic phase was separated from the aqueous phase by centrifugation at $12,000 \mathrm{xg}$ for $5 \mathrm{~min}$ and transferred to a new phase-lock gel tube PLG-H. The extraction was repeated with $500 \mu \mathrm{L}$ of $50 \%$ phenol, $50 \%$ chloroform-isoamyl alcohol and once with $100 \%$ chloroform-isoamyl alcohol. The DNA precipitation was done with 
one volume of isopropanol-sodium acetate, followed by washing with $75 \%$ ethanol. The DNA pellet was resuspended in $30 \mu \mathrm{L}$ of TrisEDTA buffer $(10 \mathrm{mM} / \mathrm{L}$ Tris and $1 \mathrm{mM} / \mathrm{L}$ EDTA, $\mathrm{pH}$ 8.0) and stored at $-20^{\circ} \mathrm{C}$ until analysis.

The oligonucleotide primers $\mathrm{LV}_{1}$ ACGAGGTCAGCTCCACTCC 3') and $\mathrm{LV}_{2}\left(5^{\prime}\right.$ CTGCAACGCCTGTGTCTACG 3') used for DNA amplification were specific for amplification of a repetitive DNA sequence of $L$. infantum (Piarroux et al., 1993). The PCR reaction mixture consisted of $10 \rho \mathrm{mol}$ of each primer, $5 \mu \mathrm{L}$ of Go Taq ${ }^{\circledR}$ Green Master Mix (Kit Go $\mathrm{Taq}^{\circledR}$ Green Master Mix, Promega, USA), $2 \mu \mathrm{L}$ of DNA template and diluted to $10 \mu \mathrm{L}$ with nuclease-free water (Kit Go Taq $^{\circledR}$ Green Master Mix, Promega, USA). Amplification was carried out using an initial denaturation step (5 min, $95^{\circ} \mathrm{C}$ ) followed by 33 cycles of annealing (30 sec, $\left.59^{\circ} \mathrm{C}\right)$, extension $\left(30 \mathrm{sec}, 72^{\circ} \mathrm{C}\right)$ and denaturation $\left(30 \mathrm{sec}, 94^{\circ} \mathrm{C}\right)$, and a final extension step $\left(2 \mathrm{~min}, 72^{\circ} \mathrm{C}\right)$. PCR products were analyzed by gel electrophoresis on a $5 \%$ non-denaturing polyacrylamide gel in $89 \mathrm{mM}$ Tris-borate buffer (pH 8.0) containing $2 \mathrm{mM}$ EDTA. Fragments were visualized by silver nitrate staining.

The DNA of $L$. infantum (MHOM/BR/1967/BH46) was used as positive control of the reaction. For negative control, all the procedures were performed, except the inclusion of the oligonucleotide primers.

To compare percentages of positive PCR reaction for semen and smegma samples, Fisher's exact test was used. Significance was considered if $\mathrm{P}<0.05$. To establish the agreement between semen and smegma sample reactions, the Kappa index was used (Landis and Koch, 1977).

This study was approved by the Animal Experimentation Ethics Committee of the Federal University of Minas Gerais, Brazil (CETEA/UFMG), with protocol number $177 / 2007$.

\section{RESULTS}

Data in Table 1 include the results of PCR analysis of semen and smegma samples collected from dogs with VL. For semen, 5 of $12 \mathrm{dogs}$
(41.7\%) had positive PCR reaction, and for smegma, 6 of 12 dogs $(50.0 \%)$. These percentages were similar $(\mathrm{P}>0.05)$. On the whole, 7 of 12 dogs $(58.3 \%)$ had positive PCR reaction for semen and/or smegma, and 4 of 12 (33.3\%) where positive for both semen and smegma. However, 1 of $12(8.3 \%)$ was positive only for semen; and 2 of $12(16.7 \%)$ were positive only for smegma. Negative PCR reaction for both semen and smegma was observed in 5 of 12 dogs $(41.7 \%)$. The Kappa index $(\mathrm{K}=0.5)$ revealed a moderate agreement (Landis and Koch, 1977) between semen and smegma results. The semen and smegma electrophoresis gel with PCR results are shown in Figure 1.

Table 1. PCR identification of Leishmania infantum DNA in the semen and smegma of dogs with Visceral Leishmaniasis

\begin{tabular}{|c|c|c|}
\hline \multirow{2}{*}{ dogs } & \multicolumn{2}{|c|}{$\mathrm{PCR}^{\mathrm{a}}$} \\
\hline & semen & smegma \\
\hline \multicolumn{3}{|l|}{ negative control } \\
\hline (C-) & - & - \\
\hline \multicolumn{3}{|l|}{ positive control } \\
\hline 1 & - & + \\
\hline 2 & + & + \\
\hline 3 & - & - \\
\hline 4 & - & - \\
\hline 5 & - & - \\
\hline 6 & + & + \\
\hline 7 & + & - \\
\hline 8 & - & + \\
\hline 9 & + & + \\
\hline 10 & - & - \\
\hline 11 & - & - \\
\hline 12 & + & + \\
\hline total + & $5 / 12(41.7 \%)^{b}$ & $6 / 12(50.0 \%)^{b}$ \\
\hline $\begin{array}{c}\text { total }+(\text { semen } \\
\text { and/or smegma) }\end{array}$ & \multicolumn{2}{|c|}{$7 / 12(58.3 \%)$} \\
\hline \multicolumn{3}{|l|}{$\begin{array}{l}\text { PCR of semen } \\
\text { and smegma }\end{array}$} \\
\hline+ and + & \multicolumn{2}{|c|}{$4 / 12(33.3 \%)$} \\
\hline+ and - & \multicolumn{2}{|c|}{$1 / 12(8.3 \%)$} \\
\hline - and + & \multicolumn{2}{|c|}{$2 / 12(16.7 \%)$} \\
\hline - and - & \multicolumn{2}{|c|}{$5 / 12(41.7 \%)$} \\
\hline
\end{tabular}

a) PCR results: + , positive reaction; -, negative reaction; b) The percentages of positive PCR reaction are similar ( $\mathrm{P}>0.05$; Fisher's exact test); c) The agreement between semen and smegma results are moderate $(\mathrm{K}=0.5$; Kappa index $)$. 


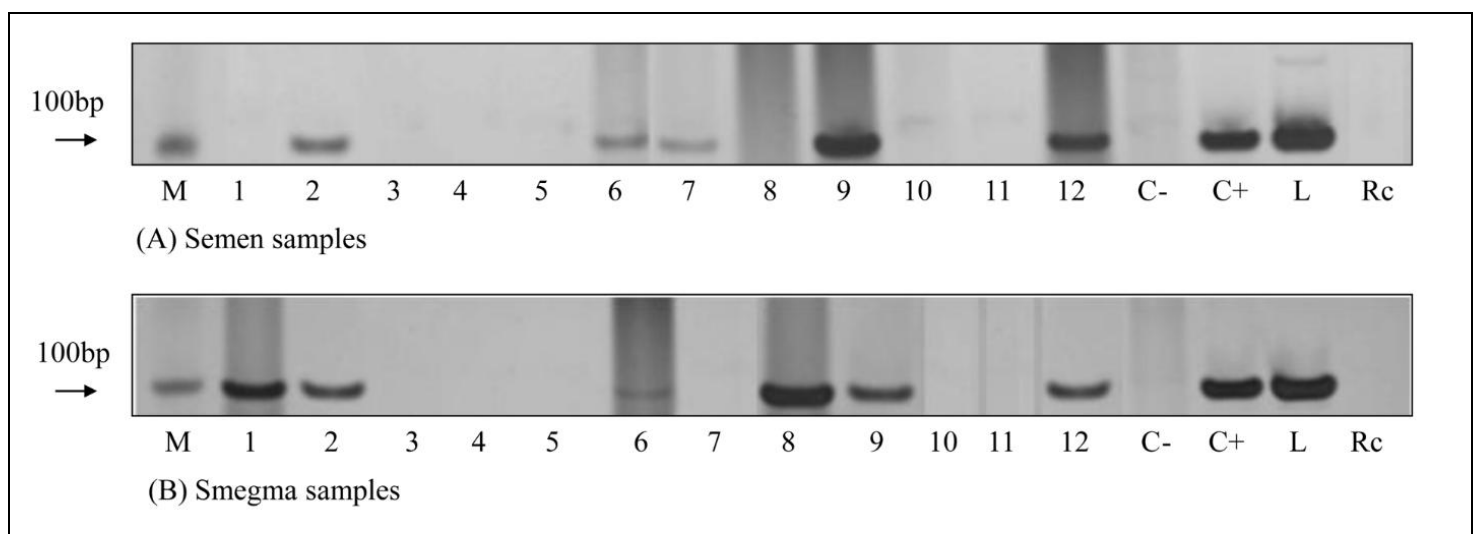

Figure 1. Detection of Leishmania infantum DNA in semen (A) and smegma (B) samples of infected dogs (1 to 12). Molecular weight markers for 100bp (Promega) (M); dog negative control (C-); dog positive control (C+); DNA of Leishmania infantum control (L); reaction control (Rc).

\section{DISCUSSION}

The identification of $L$. infantum DNA on the smegma of infected dogs shows that the venereal transmission of VCL, demonstrated by Silva et al. (2009a), could result not necessarily from deposition of the infected semen in the female genital tract, but also from the contact of the smegma of the infected dogs with the vulvo/vaginal mucosae of the bitch, regardless of the ejaculation inside the bitch, or with the oral mucosae of the bitch. In their work, Silva et al. (2009a) affirmed that infected dogs were with the experimental bitches in heat for a certain period of time, until they copulated naturally. Probably, during this time, the typical sexual behavior of the canine species occurred, and some licking and sniffing of the prepucial/penile region of the dog by the bitch could happen. The oral contamination by Leishmania sp. is not reported elsewhere in dogs, despite the artificial contamination of hamsters after oral inoculation of macerates of $L$. infantum infected ticks (Coutinho et al., 2005). The hypothesis of canine oral contamination by $L$. infantum should be tested.

The collection of the smegma before semen collection aims to avoid smegma contamination with some contaminated semen, which might make results unclear. In this way, the possibility of smegma contamination by contaminated semen is despised, which suggests the passage of Leishmania forms from tissue to the preputial/penile surface. The identification of $L$. infantum by PCR on conjunctival swab samples from infected dogs is related (Leite et al., 2010), which shows the passage of the parasite from tissue to the mucosae surface in the eye. Diniz et al. (2005) found high percentage of amastigote forms of $L$. infantum on explants of the glans penis and preputial sheath of infected dogs $(75 \%$ and $80-95 \%$, respectively), but its presence on the smegma was not investigated. It is demonstrated now.

The PCR positivity of collected semen from dogs in this experiment $(5 / 12-41.7 \%)$ is slightly higher than that obtained by Diniz et al. (2005) $(8 / 22-36.4 \%)$, but lower than that obtained by Silva et al. (2009a) (13/15 - 86.6\%), who performed three serial semen collections of each dog. Silva et al. (2009a) said that the intermittency of the positivity for $L$. infantum in the semen could be explained by some incomplete ejaculations obtained from the dogs. It can explain the lower percentage of positivity observed by Diniz et al. (2005), who performed only one collection of semen for each dog without concerning themselves with the presence or not of the sperm rich fraction. However, after using only semen collected with the sperm rich epididymal fraction, we still have a lower percentage of semen positivity than Silva et al. (2009a), which brings about an intriguing question: where is this semen Leishmania from? The answer will be helpful to establish, in the future, reproductive protocols to avoid venereal transmission of L. infantum between dogs.

The high percentage of amastigote forms on the epididymal tissue (60-95\%) associated to the inflammation of the epididymis (70-85\%) in infected dogs encouraged Diniz et al. (2005) to 
suspect that the origin of the L. infantum found in the semen collected from their experimental dogs was the epididymis. Contributing to their hypothesis, Assis et al. (2010) found semen with sperm defects suggestive of epididymal disfunction on $L$. infantum infected dogs. Therefore, a high percentage of positivity was expected in the semen (collected in our experiment) with sperm rich fraction. However, that did not occur. There probably exists another source of Leishmania for the semen, different from the epididymis, and it can be the prostate gland or preputial sheath smegma.

The prostate gland is the source of the first and third fractions of the semen (Johnston et al., 2001), and Diniz et al. (2005) found L. infantum amastigote forms in $52.6-57.9 \%$ of the prostate glands in infected dogs. The prostate gland source of Leishmania for the semen is not established.

The percentage of positive PCR in semen $(41.7 \%)$ and smegma $(50.0 \%)$ was similar $(\mathrm{P}>0.05)$, but some infected dogs have positive semen and negative smegma $(8.3 \%)$ or positive smegma and negative semen $(16.7 \%)$, which reveals that, in $25.0 \%$ of the infected dogs studied here, a negative exam of one of the samples (semen and smegma) cannot despise the risk to infect a bitch with the dog in natural mating. The only moderate (Landis and Koch, 1977) agreement between semen and smegma sample results $(\mathrm{K}=0.5)$ reveals that contamination can be independent of each other. Also, if contamination of a non-infected semen occurs with an infected smegma during semen collection, even an artificially inseminated bitch may be contaminated. The widely used semen collection procedure in dogs includes prepuce and penile manipulation (Johnston et al., 2001), and it can cause contamination of the collected semen with smegma.

\section{CONCLUSION}

In conclusion, our data support the possibility that venereal contamination of bitches from dogs infected with $L$. infantum can also result from the contact of the female with the preputial/penile surface and/or smegma, regardless of the infectious condition of the semen. Furthermore, the origin of $L$. infantum in the contaminated semen of infected dogs does not seem to be only from epididymis, as hypothesized before, but also from smegma.

\section{ACKNOWLEDGEMENTS}

We are grateful to Clínica Veterinária Santo Agostinho's staff and the Municipal Zoonotic Diseases Control Department of Betim, Minas Gerais, Brazil, for their collaboration. This work was supported by PROBIC (2006/321) and FIP (2006/1346-S2) PUC Minas, Brazil; by PIBIC/CNPq, Brazil; and by FAPEMIG, Brazil.

\section{REFERENCES}

ALVAR, J.; VÉLEZ, I.D.; BERN, C. et al. Leishmaniasis worldwilde and global estimates of its incidence. Plos One, v.7, e35671, 2012.

ASSIS, V.P.; RIBEIRO V.M.; RACHID M.A. et al. Dogs with Leishmania chagasi infection have semen abnormalities that partially revert during 150 days of Allopurinol and Amphotericin B therapy. Anim. Reprod. Sci., v.117, p.183-186, 2010.

CIARAMELLA, P.; OLIVA, G.; DE LUNA, R.D. et al. A retrospective clinical study of canine leishmaniasis in 150 dogs naturally infected by Leishmania infantum. Vet. Rec., v.141, p.539-543, 1997.

COUTINHO, M.T.Z.; BUENO, L.L.; STERZIK, A. et al. Participation of Rhipicephalus sanguineus (Acari: Ixodidae) in the epidemiology of canine visceral leishmaniasis. Vet. Parasitol., v.128, p.149-155, 2005.

DINIZ, S.A.; MELO, M.S.; BORGES, A.M. et al. Genital lesions associated with visceral leishmaniasis and shedding of Leishmania sp. in the semen of naturally infected dogs. Vet. Pathol., v.42, p.650-658, 2005.

FREITAS, E.; MELO, M.N.; COSTA-VAL, A.P. et al. Transmission of Leishmania infantum via blood transfusion in dogs: potential for infection and importance of clinical factors. Vet. Parasitol., v.137, p.159-167, 2006.

JOHNSTON, S.D.; KUSTRITZ, M.V.R.; OLSON, P.N.S. Breeding management and artificial insemination of the bitch. In: JOHNSTON, S.D.; KUSTRITZ, M.V.R.; OLSON, P.N.S. (Ed) Canine and feline theriogenology. Philadelphia: W.B. Saunders, 2001. p.41-65. 
KAMHAWI, S. Phlebotomine sand flies and Leishmania parasites: friends or foes? Trends Parasitol., v.22, p.439-445, 2006.

LANDIS, J.R.; KOCH, G.G. The measurement of observer agreement for categorical data. Biometrics, v.33, p.159-174, 1977.

LEITE, R.S.; FERREIRA, S.A.; ITUASSU, L.T. PCR diagnosis of visceral leishmaniasis in asymptomatic dogs using conjunctival swab samples. Vet. Parasitol., v.70, p.201-206, 2010.

MAURICIO, I.L.; HOWARD, M.K.; STOTHARD, J.L. Genomic diversity in the Leishmania donovani complex. Parasitology, v.119, p.237246, 1999.

MOREIRA, M.A.; LUVIZOTTO, M.C.; GARCIA, J.F. Comparison of parasitological, immunological and molecular methods for the diagnosis of leishmaniasis in dogs with different clinical signs. Vet. Parasitol., v.145, p.245-252, 2007

OWENS, S.D.; OAKLEY, D.A.; MARRYOT, $\mathrm{K}$. et al. Transmission of visceral leishmaniasis through blood transfusions from infected English foxhounds to anemic dogs. J. Am. Vet. Med. Assoc., v.219, p.1076-1083, 2001.
PIARROUX, R.; AZAIEZ, R.; LOSSI, A.M. et al. Isolation and characterization of a repetitive DNA sequence from Leishmania infantum: development of a visceral leishmaniasis polymerase chain reaction. Am. J. Trop. Méd. Hyg., v.49, p.364-369, 1993.

SILVA, F.L.; OLIVEIRA, R.G.; SILVA, T.M.A. et al. Venereal transmission of canine visceral leishmaniasis. Vet. Parasitol., v.160, p.55-59, 2009a.

SILVA, F.L.; RODRIGUES, A.A.M.; REGO, I.O.P. et al. Genital lesions and distribution of amastigotes in bitches naturally infected with Leishmania chagasi. Vet. Parasitol., v.151, p.8690, 2008.

SILVA, S.M.; RIBEIRO, V.M.; RIBEIRO, R.R. et al. First report of vertical transmission of Leishmania (Leishmania) infantum in a naturally infected bitch from Brazil. Vet. Parasitol., v.166, p.159-62, 2009b.

STRAUSS-AYALI, D.; JAFFE, C.L.; BURSHTAIN, O. et al. Polymerase chain reaction using noninvasively obtained samples, for the detection of Leishmania infantum DNA in dogs. J. Infect. Dis., v.189, p.1729-1733, 2004. 